\title{
Evaluation of Preemergence and POST-directed Herbicides on Rootstock Safety in Field-grown Almond Nursery Stock
}

\author{
Mary Joy M. Abit and Bradley D. Hanson ${ }^{1}$
}

AdDitional InDEX wORDs. herbicide screening, Prunus, rootstock safety, tree nursery

SuMMARY. Producers of fruit and nut tree nursery stock need effective weed control for maximum production of vigorous, high-grade planting material. Current weed practices include methyl bromide fumigation, preemergence herbicides, hand labor, and multiple tillage operations. As methyl bromide use is phased out due to air quality concerns, and fuel and labor costs continue to increase, herbicides are likely to become even more important for weed management in the nursery industry. Before new herbicides can be registered and used in stonefruit (Prunus sp.) tree nurseries, weed control efficacy and crop safety data are needed under local conditions. Eleven experiments were conducted from 2007 to 2011 in California tree nurseries to evaluate the crop safety of preemergence (PRE) and postemergence (POST-directed) applications of various herbicides on commonly grown peach (Prunus persica), plum (Prunus domestica), and peach/plum hybrid rootstocks budded to almond (Prunus dulcis) scions. Rootstocks grown from cuttings generally were more tolerant to herbicides than those grown from seed. Crop safety was adequate in seeded and vegetatively propagated rootstocks with oryzalin, pendimethalin, and isoxaben, all of which are labeled for use in tree nurseries. The unregistered herbicides, dithiopyr, rimsulfuron, oxyfluorfen, and foramsulfuron; as well as lower rates of indaziflam and penoxsulam; applied PRE and POSTdirected can provide good to excellent weed control in some stonefruit rootstocks. However, because slight crop injury was occasionally observed, additional work on application rates, timing, and method of application, especially on nonlabeled herbicides is needed before these materials can be considered for registration and broad scale use in tree nurseries.

$\mathrm{C}$ alifornia nursery operations combined to produce $\$ 165.5$ million in wholesale value of fruit and nut tree planting stock-a value that is multiplied severalfold by retailers and exporters (U.S. Department of Agriculture, 2007). Fruit and nut tree nursery production practices in California vary among growers, regions, and tree species; however, production cycles usually follow a similar schedule (Hanson and Schneider, 2008). Generally, a rootstock is planted in the field in the fall as either seed or cuttings, a scion variety is grafted or budded onto the rootstock the

\footnotetext{
Department of Plant Sciences, University of California, Davis, MS-4, One Shields Ave, Davis, CA 95616

Funding for this research was provided by the Fruit Tree, Nut Tree, and Grapevine Improvement Advisory Board (IAB) and USDA-ARS Pacific Areawide Pest Management Program for Integrated Methyl Bromide Alternatives. The authors thank Sierra Gold Nurseries, Burchell Nursery, and Fowler Nursery for in-kind donations of field space, planting stock, and crop management in these trials. The technical support of Dr. Amit Jhala and Marcelo Moretti is acknowledged and appreciated and we thank Drs. Tom Lanini and Lynn Sosnoskie for reviewing an early version of this manuscript.
}

${ }^{1}$ Corresponding author. E-mail: bhanson@ucdavis.edu. following spring or fall, and the trees are harvested and sold as bare-root planting stock after one or two growing seasons. Most almond and stonefruit trees produced in this system are grown as 14-month crops on peach, plum, or hybrid rootstocks.

Weed control is an ongoing management problem faced by producers of field-grown nursery stock. Competition from weeds can decrease crop productivity and interfere with field and harvest operations. Weed management techniques include preplant soil fumigation with methyl bromide, preemergence herbicides, hand labor, and multiple tillage operations (Schneider et al., 2003). Methyl bromide and its potential replacement alternatives do not always provide sufficient weed control over the 1-3 year nursery tree cropping cycle. Reasons for incomplete control with fumigants include hard/impermeable weed seedcoats that prevent fumigant penetration, reinvasion of weeds into the field, reduced fumigant solubility and dispersion in response to environmental conditions (e.g., inappropriate soil moisture content) (Hanson and Shrestha, 2006). This problem will likely be compounded by the use of fumigants other than methyl bromide which is being phased out due to environmental concerns (United Nations Environmental Program, 1999; Zasada et al., 2010). Hand labor can be an effective means of controlling weeds within rows of nursery stock but can result in mechanical crop damage, requires a large and expensive labor force, and is subject to stringent worker safety regulations. Although several herbicides are labeled for use in tree nurseries, residual herbicide options are limited during the critical rootstock emergence and early season growth period by crop safety concerns (Zheljazkov et al., 2007). Some herbicides can injure either crop roots (stunting or malformations) or aboveground portions of the plant (meristem damage, stem malformations, stunting, and chlorosis). Plants with visual root or stem defects are unacceptable to the buyers and are usually destroyed.

As other options become more expensive or difficult to use, it is likely that herbicides will become an even more important part of integrated pest management in nursery crops (Altland et al., 2003; Gilliam et al., 1989). Identification of herbicides and herbicide application techniques that provide economical, effective, and safe in-season weed control will provide growers with additional management options for production of fruit and nut tree nursery stock.

\begin{tabular}{lllc}
\hline $\begin{array}{l}\text { Units } \\
\text { To convert U.S. to SI, } \\
\text { multiply by }\end{array}$ & U.S. unit & SI unit & $\begin{array}{l}\text { To convert SI to U.S., } \\
\text { multiply by }\end{array}$ \\
\hline 0.3048 & $\mathrm{ft}$ & $\mathrm{m}$ & 3.2808 \\
0.0929 & $\mathrm{ft}^{2}$ & $\mathrm{~m}^{2}$ & 10.7639 \\
9.3540 & gal/acre & ${\mathrm{L} \cdot h a^{-1}}^{2}$ & 0.1069 \\
2.54 & inch $(\mathrm{es})$ & $\mathrm{cm}$ & 0.3937 \\
25.4 & inch $(\mathrm{es})$ & $\mathrm{mm}$ & 0.0394 \\
1.1209 & lb/acre & $\mathrm{kg} \cdot \mathrm{ha}^{-1}$ & 0.8922 \\
0.0254 & mil & $\mathrm{mm}$ & 39.3701
\end{tabular}


Several new herbicides have been registered in orchard crops for control of a broad spectrum of weeds; however, these herbicides are not currently labeled for use in tree nurseries and the safety of these materials to common peach, plum, and peach/ plum hybrid rootstocks used in production of stonefruit and almond nursery stock is not known. The objective of this work was to evaluate weed control efficacy and nursery rootstock safety of several PRE and POST-directed herbicide treatments in commercial tree nursery production systems.

\section{Materials and methods}

A series of 11 experiments was conducted in commercial tree nurseries near Oakdale, CA (lat. $37^{\circ} 46^{\prime} 24^{\prime \prime} \mathrm{N}$; long. $\left.120^{\circ} 46^{\prime} 25^{\prime \prime} \mathrm{W}\right)$; Newcastle, CA (lat. 38 $53^{\prime} 32^{\prime \prime} \mathrm{N}$; long. $\left.121^{\circ} 13^{\prime} 14^{\prime \prime} \mathrm{W}\right) ;$ and Yuba City, CA (lat. $39^{\circ} 3^{\prime} 6^{\prime \prime} \mathrm{N}$; long. $\left.121^{\circ} 36^{\prime} 54^{\prime \prime} \mathrm{W}\right)$ from 2007 to 2011 in rootstocks commonly used in stonefruit and almond production (Table 1). Before planting, cooperating growers prepared the fields for preplant fumigation using appropriate tillage and soil moisture management techniques. Nursery blocks were commercially fumigated with either methyl bromide [ $\mathrm{MeBr}(300 \mathrm{lb} /$ acre $)]$ or a split (dual) application of 1,3dichloropropene [1,3-D (332 lb/acre followed by $142 \mathrm{lb} /$ acre)]. Methyl bromide was applied with a Noble plow fumigation rig with injection points 12 inches deep and a spacing of 12 inches between nozzles. Plots were sealed with 1-mil high-density polyethylene film immediately following fumigation. The 1,3-D (97.5\% 1,3-D and $2.5 \%$ inert ingredient, Telone II; Dow AgroSciences, Indianapolis, IN) was applied with a fumigation rig with injection points 18 inches deep and 20 inches between nozzles in sequential applications $14 \mathrm{~d}$ apart (California Department of Food and Agriculture, 2013). PRE and POST-directed applications of registered and nonregistered herbicides were applied to the plots before and following rootstock seeding and emergence, respectively, using a carbon dioxide pressurized backpack sprayer calibrated to deliver 20 to $40 \mathrm{gal} /$ acre. PRE treatments were applied as a band over the tree row after seeding the rootstock but before emergence and POST-directed treatments were applied to the soil at the base of the trees using a directed or shielded spray boom to minimize crop exposure to the herbicide.

The cooperating growers thinned, pruned, and fertilized the rootstock and then spring-budded the trees to almond scions using standard production practices. Crop injury and weed control were visually rated using a scale of 0 (no injury or no weed control) to
$100 \%$ (crop death or complete weed control) throughout the 14-month growing season; however, weed data are presented only for selected sites and years due to confounding effects of growers' cultivation and weed management efforts at other sites (Table 1). All experiments were arranged as randomized complete block designs with four replications; individual herbicide plots were $3 \times 25 \mathrm{ft}$ and contained a single row of trees. All established trees in a 10- to 25 -ft-long section of each plot were counted after rootstock establishment and scion budding; trunk diameter (caliper) of 10 adjacent trees near the middle of each plot was measured 2 inches above the graft union before harvest.

2007-08. Five field experiments were conducted to evaluate PRE herbicide treatments applied over the seeded crop row before either the rootstock or weeds emerged or POSTdirected treatments applied when actively growing weeds and nursery stock were present. In the two peach rootstock experiments near Oakdale, CA, PRE herbicide treatments were applied in a band over the planted tree row on 28 Feb. 2008 before the rootstock seedlings emerged (Table 2 ). In the three POST-directed experiments near Newcastle, CA, applications were directed at the base of the emerged trees on 30 Apr. 2008 before budding when the peach rootstocks were

Table 1. Location parameters for 11 herbicide trials conducted in commercial, in-ground almond tree nursery production systems in California from 2007 to 2011.

\begin{tabular}{|c|c|c|c|c|c|}
\hline $\begin{array}{l}\text { Growing } \\
\text { season }\end{array}$ & Location $^{\mathrm{z}}$ & $\begin{array}{l}\text { Herbicide } \\
\text { placement }^{y}\end{array}$ & $\begin{array}{c}\text { Application } \\
\text { date }\end{array}$ & $\begin{array}{c}\text { Rootstock variety } \\
{\text { (propagation method })^{\mathrm{x}}}\end{array}$ & Data collected $^{\mathrm{w}}$ \\
\hline $2007-08$ & Oakdale & PRE & 28 Feb. 2008 & Nemaguard peach (seeded) & Crop safety \\
\hline $2007-08$ & Newcastle & POST-directed & 30 Apr. 2008 & Nemaguard peach (seeded) & Crop safety \\
\hline $2007-08$ & Newcastle & POST-directed & 30 Apr. 2008 & Lovell peach (seeded) & Crop safety \\
\hline $2007-08$ & Newcastle & POST-directed & 30 Apr. 2008 & Marianna 2624 plum (cuttings) & Crop safety \\
\hline 2008-09 & Newcastle & POST-directed & 5 Mar. 2009 & Krymsk86 peach/plum (cuttings) & $\begin{array}{l}\text { Crop safety } \\
\text { and weed control }\end{array}$ \\
\hline $2009-10$ & Oakdale & POST-directed & 13 May 2010 & Nemaguard peach (seeded) & Crop safety \\
\hline $2010-11$ & Newcastle & POST-directed & 8 Jan. 2011 & Marianna 2624 plum (cuttings) & $\begin{array}{l}\text { Crop safety } \\
\text { and weed control }\end{array}$ \\
\hline
\end{tabular}

${ }^{2}$ Soil at the Oakdale site was a loamy sand, soil at the Newcastle site was a sandy loam, and soil at the Yuba City site was a silty clay loam. The Oakdale and Yuba City sites were fumigated with methyl bromide and the Newcastle site was fumigated with 1,3-dichloropropene before planting.

y PRE herbicide treatments were applied in a band over the seeded tree row before rootstock seedling emergence; POST-directed applications were made to the soil at the base of the trees to minimize direct foliar and trunk exposure to the herbicides.

${ }^{x}$ All rootstocks were budded to almond scions in May or June.

"Crop safety evaluations included rootstock establishment, budding success, and almond scion trunk diameter at harvest; weed control evaluations included visual assessments of control and weed density counts. 
12 inches tall and the plum rootstock was $\approx 16$ inches tall (Table 3 ).

2008-09. Three field experiments were conducted at nurseries near Newcastle and Yuba City, CA to evaluate herbicide treatments containing isoxaben, dithiopyr, pendimethalin, oxyfluorfen, thiazopyr, and rimsulfuron (Table 4). PRE herbicide treatments were applied on 13 Apr. 2009 in separate experiments in 'Nemaguard' and 'Lovell' peach rootstock blocks at the Yuba City site. At the Newcastle site, POST-directed herbicide applications were made at the base of still-dormant 'Krymsk86' hardwood cuttings on 5 Mar. 2009.

2009-10. A trial was conducted at a nursery near Oakdale, CA to evaluate nursery crop safety with several unregistered herbicides including rimsulfuron, penoxsulam, foramsulfuron, and indaziflam (Table 5). Herbicides were applied as POST-directed treatments with a shielded sprayer on 13 May 2010 before budding when the 'Nemaguard' peach rootstock was $\approx 16$ inches tall.

2010-11. Based on the results of the 2009-10 trial, two additional experiments were conducted at the Newcastle, CA site to evaluate the effects of PRE and POST-directed herbicide applications (Table 6). Herbicide treatments were applied PRE on 8 Jan. 2011 over the top of the seeded 'Nemaguard' tree row and as unshielded POST-directed applications in newly planted 'Marianna 2624' plum cuttings.

Statistical anAlysis. All data were subjected to analysis of variance (ANOVA) and means were separated using Fisher's protected least significant difference (LSD) test with $P \leq 0.05$ (SAS version 9.1; SAS Institute, Cary, NC). Data were transformed as needed to meet ANOVA assumptions; however, data were back transformed for presentation. Data from each field experiment and year were analyzed separately.

\section{Results and discussion}

2007-08. One month after treatment at the Oakdale location, 'Nemaguard' and 'Lovell' peach

Table 2. Effects of preemergence herbicide treatments on establishment and growth of peach rootstocks budded to almond scions in two tree nursery trials near Oakdale, CA in 2008.

\begin{tabular}{|c|c|c|c|c|c|c|c|}
\hline \multirow[b]{2}{*}{$\begin{array}{l}\text { Herbicide } \\
\text { treatment }^{\mathrm{z}}\end{array}$} & \multirow[b]{2}{*}{$\begin{array}{c}\text { Rate } \\
(\mathrm{lb} / \text { acre })^{\mathrm{z}} \\
\end{array}$} & \multicolumn{3}{|c|}{ 'Nemaguard' peach rootstock } & \multicolumn{3}{|c|}{ 'Lovell' peach rootstock } \\
\hline & & $\begin{array}{c}\text { Visual injury } \\
(\%)^{\mathrm{y}}\end{array}$ & $\begin{array}{l}\text { Established trees } \\
{\text { (no./25-ft row })^{\mathrm{y}}}\end{array}$ & $\begin{array}{c}\text { Trunk } \\
\operatorname{diam}(\mathrm{mm})^{\mathrm{y}}\end{array}$ & $\begin{array}{c}\text { Visual } \\
\text { injury (\%) }\end{array}$ & $\begin{array}{l}\text { Established trees } \\
\text { (no./25-ft row) }\end{array}$ & $\begin{array}{c}\text { Trunk } \\
\operatorname{diam}(\mathrm{mm})\end{array}$ \\
\hline Nontreated & - & 0 & 40 & 15 & 0 & 52 & 14 \\
\hline Oryzalin & 1.0 & 1 & 45 & 15 & 0 & 50 & 17 \\
\hline Oryzalin & 2.0 & 1 & 45 & 17 & 4 & 51 & 14 \\
\hline Dithiopyr & 1.0 & 31 & 15 & 11 & 44 & 40 & 14 \\
\hline Pendimethalin & 1.0 & 9 & 36 & 16 & 6 & 49 & 15 \\
\hline Pendimethalin & 2.0 & 8 & 45 & 15 & 9 & 53 & 14 \\
\hline $\operatorname{LSD}(0.05)^{\mathrm{x}}$ & & 9 & 9 & 2 & 8 & 6 & NS \\
\hline
\end{tabular}

${ }^{2}$ Treatments were applied over the seeded tree row on $28 \mathrm{Feb} .2008 ; 1 \mathrm{lb} /$ acre $=1.209 \mathrm{~kg} \cdot \mathrm{ha}^{-1}$.

'Injury was rated on 17 Mar. 2008, established trees counted on 24 June 2008, and almond scion trunk diameter measured on 21 Nov. 2008 . Both rootstocks were budded to almond scions in May 2008; 1 tree $/ 25-\mathrm{ft}(7.62 \mathrm{~m})$ row $=0.1312$ tree $/ \mathrm{m}, 1 \mathrm{~mm}=0.0394$ inch.

${ }^{x}$ Fisher's protected least significant difference procedure at $P<0.05$, NS $=$ nonsignificant.

Table 3. Effects of postemergence directed herbicide treatments on establishment and growth of peach and plum rootstocks budded to almond scions in three tree nursery trials near Newcastle, CA in 2008.

\begin{tabular}{|c|c|c|c|c|c|c|c|c|c|c|}
\hline \multirow[b]{2}{*}{$\begin{array}{l}\text { Herbicide } \\
\text { treatment }^{\mathrm{y}}\end{array}$} & \multirow[b]{2}{*}{$\begin{array}{c}\text { Rate } \\
(\text { lb/acre })^{y}\end{array}$} & \multicolumn{3}{|c|}{ 'Nemaguard' peach ${ }^{\mathrm{z}}$} & \multicolumn{3}{|c|}{ 'Lovell' peach } & \multicolumn{3}{|c|}{ 'Marianna 2624' plum } \\
\hline & & $\begin{array}{c}\text { Visual } \\
\text { injury } \\
(\%)^{\mathrm{x}}\end{array}$ & $\begin{array}{c}\text { Established } \\
\text { trees } \\
(\text { no. } / 25-\mathrm{ft} \text { row })^{\mathrm{x}} \\
\end{array}$ & $\begin{array}{l}\text { Trunk } \\
\text { diam } \\
(\mathrm{mm})^{\mathbf{x}}\end{array}$ & $\begin{array}{c}\begin{array}{c}\text { Visual } \\
\text { injury } \\
(\%)\end{array} \\
\end{array}$ & $\begin{array}{c}\text { Established } \\
\text { trees } \\
\text { (no./25-ft row) }\end{array}$ & $\begin{array}{c}\text { Trunk } \\
\text { diam } \\
(\mathrm{mm})\end{array}$ & $\begin{array}{c}\text { Visual } \\
\text { injury } \\
(\%)\end{array}$ & $\begin{array}{c}\text { Established } \\
\text { trees } \\
\text { (no./25-ft row) }\end{array}$ & $\begin{array}{c}\text { Trunk } \\
\text { diam } \\
(\mathrm{mm}) \\
\end{array}$ \\
\hline Nontreated & - & 0 & 45 & 17 & 0 & 75 & 14 & 0 & 53 & 20 \\
\hline Isoxaben & 1.33 & 3 & 40 & 16 & 0 & 68 & 14 & 0 & 59 & 17 \\
\hline Dithiopyr & 1.0 & 0 & 46 & 16 & 5 & 56 & 15 & 0 & 60 & 18 \\
\hline Flumioxazin & 0.26 & 55 & 11 & 17 & 31 & 26 & 17 & 0 & 59 & 17 \\
\hline Oxadiazon & 2.0 & 4 & 44 & 15 & 0 & 60 & 15 & 3 & 56 & 19 \\
\hline Oxyfluorfen & 0.25 & 0 & 40 & 15 & 9 & 63 & 15 & 0 & 58 & 18 \\
\hline Oxyfluorfen & 0.5 & 3 & 54 & 14 & 0 & 62 & 15 & 3 & 56 & 18 \\
\hline Ethofumasate & 1.0 & 0 & 52 & 16 & 3 & 58 & 14 & 3 & 61 & 17 \\
\hline
\end{tabular}

${ }^{2}$ Peach rootstock were grown from seed and the plum rootstock was grown from cuttings. All rootstocks were budded with almond scions in May or June 2008.

${ }^{y}$ Treatments were applied as a directed application near the base of the rootstock trees on 30 Apr. $2008 ; 1 \mathrm{lb} / \mathrm{acre}=1.209 \mathrm{~kg} \cdot \mathrm{ha}{ }^{-1}$.

xInjury was rated on 29 May. 2008 and established trees were counted and almond scion trunk diameter measured on 26 Nov. 2008 . All rootstocks were budded with almond scions in late May $2008 ; 1$ tree $/ 25-\mathrm{ft}(7.62 \mathrm{~m})$ row $=0.1312$ tree $/ \mathrm{m}, 1 \mathrm{~mm}=0.0394$ inch.

"Fisher's protected least significant difference procedure at $P<0.05, \mathrm{NS}=$ nonsignificant. 
Table 4. Effects of postemergence directed herbicide treatments on weed control and almond scion growth on 'Krymsk86' peach/plum rootstock in a tree nursery trial near Newcastle, CA and preemergence treatments on almond scion growth on 'Nemaguard' and 'Lovell' peach rootstock in nursery experiments near Yuba City, CA in 2008.

\begin{tabular}{|c|c|c|c|c|c|c|c|}
\hline \multirow[b]{2}{*}{$\begin{array}{l}\text { Herbicide } \\
\text { treatment }^{\mathrm{z}}\end{array}$} & \multirow[b]{2}{*}{$\begin{array}{c}\text { Rate } \\
(\text { lb } / \text { acre })^{\mathrm{z}}\end{array}$} & \multicolumn{4}{|c|}{ Newcastle } & \multicolumn{2}{|c|}{ Yuba City } \\
\hline & & $\begin{array}{c}\text { Visual } \\
\text { injury } \\
(\%)^{y}\end{array}$ & $\begin{array}{c}\text { Grass } \\
\text { weed } \\
\text { control }(\%)^{y} \\
\end{array}$ & $\begin{array}{c}\text { Broadleaf } \\
\text { weed } \\
\text { control }(\%)^{y}\end{array}$ & $\begin{array}{c}\text { Almond trunk } \\
\text { diam on 'Krymsk86' } \\
\text { peach/plum }(\mathrm{mm})^{\mathrm{y}}\end{array}$ & $\begin{array}{l}\text { Almond trunk diam } \\
\text { on 'Nemaguard' } \\
\text { peach }(\mathrm{mm})\end{array}$ & $\begin{array}{c}\text { Almond trunk } \\
\text { diam on 'Lovell' } \\
\text { peach (mm) }\end{array}$ \\
\hline Isoxaben & 1.0 & 5 & 63 & 28 & 17 & 13 & 15 \\
\hline Isoxaben & 1.33 & 1 & 82 & 71 & 16 & 12 & 14 \\
\hline Pendimethalin & 1.0 & 0 & 88 & 62 & 17 & 13 & 15 \\
\hline Pendimethalin & 2.0 & 0 & 94 & 84 & 16 & 13 & 16 \\
\hline Oxyfluorfen & 0.5 & 6 & 71 & 79 & 17 & 12 & 16 \\
\hline Oxyfluorfen & 1.0 & 28 & 97 & 91 & 18 & 14 & 16 \\
\hline Thiazopyr & 0.5 & 0 & 99 & 84 & 17 & 12 & 14 \\
\hline Thiazopyr & 1.0 & 8 & 99 & 97 & 17 & 13 & 13 \\
\hline Rimsulfuron & 0.016 & 5 & 99 & 92 & 15 & 13 & 15 \\
\hline $\operatorname{LSD}(0.05)^{\mathrm{x}}$ & & 15 & 19 & 24 & 2 & 1 & 2 \\
\hline
\end{tabular}

${ }^{2}$ Treatments applied as a directed application near the base of the 'Krymsk86' rootstock cuttings on 5 Mar. 2009 and as PRE bands over the seeded peach rootstock row on 13 Apr. 2009. All rootstocks were budded to almond scions in May or June 2008 ; $1 \mathrm{lb} / \mathrm{acre}=1.209 \mathrm{~kg} \cdot \mathrm{ha}^{-1}$.

'Weed control and tree injury rated on 24 May 2009 and scion trunk diameter measured on 30 Oct. 2009 in all three experiments; 1 mm = 0.0394 inch

${ }^{x}$ Fisher's protected least significant difference procedure at $P<0.05$

Table 5. Effects of postemergence directed herbicide treatments on 'Nemaguard' peach rootstock establishment, injury, and almond scion diameter in a tree nursery trial near Oakdale CA in 2010.

\begin{tabular}{lcccc}
\hline $\begin{array}{l}\text { Herbicide } \\
\text { treatment }\end{array}$ & $\begin{array}{c}\text { Rate } \\
(\mathbf{l b} / \mathbf{a c r e})^{\mathbf{z}}\end{array}$ & $\begin{array}{c}\text { Visual } \\
\text { injury }(\%)^{\mathbf{y}}\end{array}$ & $\begin{array}{c}\text { Established trees } \\
(\mathbf{n o .} / \mathbf{1 0} \text {-ft row })^{\mathbf{y}}\end{array}$ & $\begin{array}{c}\text { Trunk } \\
\text { diam }(\mathbf{m m})^{\mathbf{y}}\end{array}$ \\
\hline Nontreated & - & 0 & 17 & 15 \\
Isoxaben & 0.66 & 0 & 17 & 16 \\
Rimsulfuron & 0.024 & 0 & 18 & 15 \\
Rimsulfuron & 0.031 & 0 & 16 & 15 \\
Dithiopyr & 1.0 & 2 & 19 & 14 \\
Dithiopyr & 2.0 & 1 & 18 & 15 \\
Dithiopyr & 3.0 & 3 & 18 & 14 \\
Penoxsulam & 0.015 & 2 & 18 & 16 \\
Penoxsulam & 0.03 & 6 & 17 & 14 \\
Indaziflam & 0.046 & 11 & 19 & 14 \\
Indaziflam & 0.065 & 7 & 15 & 10 \\
Sulfosulfuron & 0.06 & 64 & 14 & 15 \\
Foramsulfuron & 0.033 & 10 & 17 & 16 \\
Foramsulfuron & 0.044 & 6 & 18 & 3 \\
LSD $(0.05)^{\mathbf{x}}$ & & 7 & 4 & 15
\end{tabular}

${ }^{z}$ Treatment as a directed application using a shielded sprayer on 13 May 2010, the peach rootstock was budded to an almond scion in June $2010 ; 1 \mathrm{lb} / \mathrm{acre}=1.209 \mathrm{~kg} \cdot \mathrm{ha}^{-1}$.

${ }^{y}$ Crop injury was evaluated on 16 Aug. 2010 and the number of established trees were counted and almond trunk diameter was measured on 15 Dec. $2010 ; 1$ tree $/ 10-\mathrm{ft}(3.05 \mathrm{~m})$ row $=0.3281$ tree $/ \mathrm{m}, 1 \mathrm{~mm}=0.0394$ inch

${ }^{x}$ Fisher's protected least significant difference procedure at $P<0.05$.

rootstocks had minimal or no injury with PRE application of oryzalin, pendimethalin, and isoxaben, all of which are labeled in tree nurseries (Table 2). However, plants treated with dithiopyr (not labeled) were severely injured; symptoms included chlorosis, leaf malformation, and stunting and resulted in a low number of established trees (Table 2). It should be noted that the application of dithiopyr in this experiment was made just as the seedlings were beginning to emerge; dithiopyr is a PRE and an early POST herbicide, which when applied to growing tissues can cause severe injury to some species (Bhowmik and Bahnson, 1989). Applications of dithiopyr made before the seeded tree crop emerged have had acceptable crop safety in previous experiments (Hanson and Schneider, 2008).

At the Newcastle sites, significant injury to the seeded peach rootstocks was noted with POST-directed applications of flumioxazin and imazosulfuron in the seeded rootstocks but similar injury was not observed on the plum cuttings (Table 3 ). Rootstock stand establishment was reduced by flumioxazin and imazosulfuron in the 'Nemaguard' experiment and by dithiopyr, flumioxazin, imazosulfuron in the 'Lovell' experiment. Establishment of 'Marianna 2624' plum was not reduced by any treatment. Almond scion trunk diameter at harvest was reduced in some cases, particularly by imazosulfuron, but results were variable due to compensatory growth in the plots with fewer established trees.

POST-directed rimsulfuron and ethofumesate were safe in these two peach rootstock trials and should be evaluated further. The activity of these materials on several problem 
Table 6. Effects of preemergence and postemergence directed herbicide treatments on weed control and almond scion growth on 'Nemaguard' peach and 'Marianna 2624' plum rootstocks in two nursery experiments near Newcastle, CA in 2011.

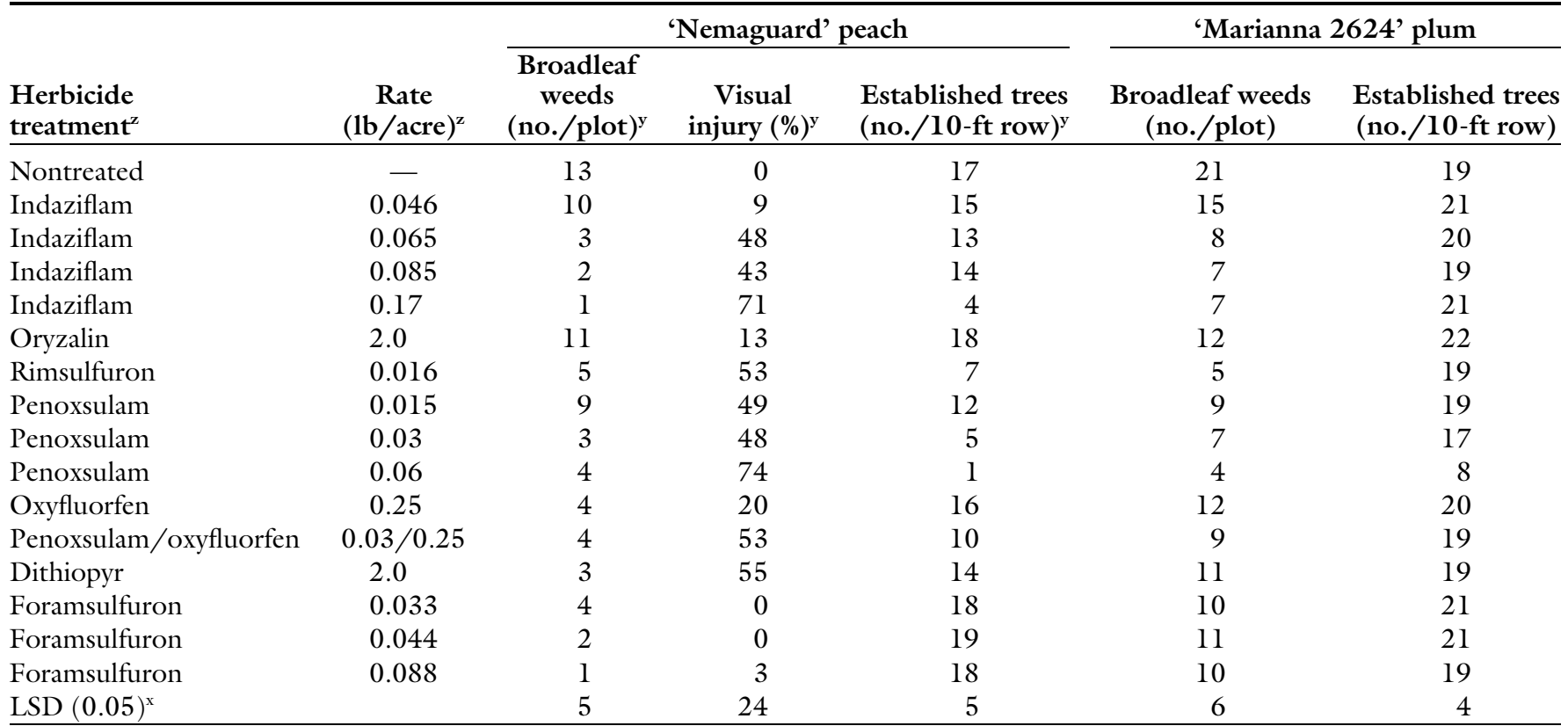

${ }^{2}$ Treatments applied as a preemergence band over the seeded peach rootstock rows and as a directed application near the base of the plum cuttings on 8 Jan. 2011 . Both rootstocks were budded to almond scions in May $201 \mathrm{l} ; \mathrm{l} \mathrm{lb} / \mathrm{acre}=1.209 \mathrm{~kg} \cdot \mathrm{ha}^{-1}$.

yAll weeds in each $3 \times 25$-ft long $\left[75 \mathrm{ft}^{2}\left(6.97 \mathrm{~m}^{2}\right)\right]$ plot were counted on 8 Apr. 2011 and the number of established trees were counted on 18 Oct. $2011 ; 1$ weed $/ 75$ - $\mathrm{ft}^{2}$ plot $=$ 0.0133 weed $/ \mathrm{ft}^{2}=0.1435$ weed $/ \mathrm{m}^{2}, \mathrm{l}$ tree $/ 10-\mathrm{ft}(3.05 \mathrm{~m})$ row $=0.3281$ tree $/ \mathrm{m}$.

${ }^{x}$ Fisher's protected least significant difference procedure at $P<0.05$.

weeds like ryegrass (Lolium sp.), annual bluegrass (Poa annua), and puncturevine (Tribulus terrestris) (Ekins and Day, 1978; Lee, 1977) could be beneficial in this cropping system if registered.

2008-09. POST-directed applications of $1 \mathrm{lb} /$ acre oxyfluorfen caused substantial injury on 'Krymsk86' cuttings in the 2009 trial near Newcastle, CA (Table 4). Grass weed control was $85 \%$ or greater with most herbicide treatments except isoxaben and the low rate of oxyfluorfen while broadleaf control was less than $80 \%$ with isoxaben and low rates of pendimethalin $(1 \mathrm{lb} /$ acre $)$ and oxyfluorfen $(0.5$ $\mathrm{lb} / \mathrm{acre})$. Despite early season injury by oxyfluorfen ( $6 \%$ to $28 \%$ ), tree establishment and final trunk diameter measurements were not reduced. All other herbicide treatments had acceptable crop safety to the 'Krymsk86' peach/plum hybrid rootstock. In the two peach rootstock experiments near Yuba City, slight to no injury from PRE treatments was observed on the 'Nemaguard' and 'Lovell' rootstocks and almond scion trunk caliper was not reduced compared with the nontreated control by any treatment (Table 4). The most promising materials in these experiments from a crop safety and weed control standpoint were dithiopyr (not labeled) and rimsulfuron (not labeled) in addition to the labeled materials, pendimethalin and thiazopyr. Although minor crop injury was noted one month after the POST-directed application of dithiopyr in the peach/ plum hybrid rootstock, the symptoms were transient and weed control was greater than $90 \%$. Oxyfluorfen provided good to excellent weed control either alone or in combination with pendimethalin and was relatively safe at the $0.5-\mathrm{lb} /$ acre rate.

2009-10. With the exception of sulfosulfuron, POST-directed herbicide treatments caused little injury to 'Nemaguard' peach rootstock at the Oakdale site in 2010 (Table 5). POST-directed applications of sulfosulfuron caused $64 \%$ crop injury 3 months after treatment. Almond scion trunk diameter at harvest was reduced by the sulfosulfuron treatment compared with the nontreated control. Isoxaben (labeled) was safe to the 'Nemaguard' peach rootstock in this application and the unlabeled materials dithiopyr, rimsulfuron, penoxsulam, indaziflam, and foramsulfuron were also relatively safe in this experiment.

2010-11. All PRE treatments except oryzalin and low rates of indaziflam and penoxsulam provided good to excellent control of broadleaf weeds in the peach experiment (Table 6). However, with the exception of foramsulfuron, most of the unregistered herbicides caused significant injury to the emerging 'Nemaguard' peach seedlings. One month after PRE applications, significant stunting and malformation were observed in plots treated with dithiopyr, rimsulfuron, penoxsulam + oxyfluorfen, and high rates of indaziflam and penoxsulam; but these symptoms were not apparent by the April rating (data not shown). Low seedling establishment was observed in plots treated with rimsulfuron and in plots treated with the highest rates of indaziflam and penoxsulam. Due to large variability in tree establishment throughout this field, no differences in final almond trunk measurements were observed (data not shown).

In the 'Marianna 2624' plum rootstock experiment, herbicide treated plots had $48 \%$ to $76 \%$ lower broadleaf weed density compared with the nontreated control. Rimsulfuron and high rates of indaziflam and penoxsulam provided the greatest weed control, however, penoxsulam at $0.06 \mathrm{lb} /$ acre significantly reduced tree establishment. No differences in almond scion trunk diameter were noted among 
treatments in this experiment (data not shown).

\section{Conclusion}

Crop safety is of vital importance in nursery tree production because stunting or visual defects could result in nonmarketable trees at harvest. Overall, crop safety was better when the treatments were applied as a PRE or POST-directed application to plum or peach/plum cuttings as compared with the seeded peach rootstocks. Although this may reflect an inherent susceptibility difference between peach and plum, it is more likely due to differences in root and shoot exposure to the herbicides for these two types of rootstocks. To date, crop safety has been acceptable with oryzalin, pendimethalin, and isoxaben; all of which are labeled in tree nurseries. Dithiopyr, rimsulfuron, oxyfluorfen, foramsulfuron, and lower rates of indaziflam and penoxsulam can provide good weed control and have had promising crop safety in some experiments. However, considerable work on herbicide rates, timing, and method of application are needed before these materials can be safely applied to newly planted rootstock on a broader scale.

\section{Literature Cited}

Altland, J.E., C.H. Gilliam, and G. Wehtje. 2003. Weed control in field nurseries. HortTechnology 13:9-14.

Bhowmik, P.C. and B.M. Bahnson. 1989. Pre and post emergence smooth crabgrass control with MON-15151 in cool season turfgrass. Proc. Northeast Weed Sci. Soc. 43:110. (Abstr.).

California Department of Food and Agriculture. 2013. Nursery inspection procedures manual [NIPM] Item \#7. 23 May 2013. <www.cdfa.ca.gov/plant/ pe/Nursery/pdfs/NIPM_7.pdf>.

Ekins, W.L. and M.G. Day. 1978. The results of two years testing with ethofumesate under an experimental use permit in grass seed crops. Proc. Western Soc. Weed Sci. 31:98. (Abstr.).

Lee, W.O. 1977. Winter annual grass weed control in Italian ryegrass with ethofumesate. Weed Sci. 25:252-255.

Gilliam, C.H., G. Wehtje, J.E. Eason, T.J. Hicks, and D.C. Fare. 1989. Weed control with Gallery and other herbicides in field-grown nursery crops. J. Environ. Hort. 7:69-72.

Hanson, B.D. and S.A. Schneider. 2008. Evaluation of weed control and crop safety with herbicides in open field tree nurseries. Weed Technol. 22:493-498.

Hanson, B. and A. Shrestha. 2006. Weed control with methyl bromide alternatives.
CAB Rev. Perspectives Agr. Veterinary Sci. Nutr. Natural Resources 1:1-13. 23 May 2013. <http://www.cabi.org/cabreviews/ ShowPDF.aspx?PAN=20073043257>.

Schneider, S.M., E.N. Rosskopf, J.G. Leesch, D.O. Chellemi, C.T. Bull, and M. Mazzola. 2003. United States Department of Agriculture-Agricultural Research Service research on alternatives to methyl bromide: Pre-plant and post-harvest. Pest Mgt. Sci. 59:814-826.

U.S. Department of Agriculture. 2007. Nursery crops 2006 summary. 4 Apr. 2013. <http://usda01.library.cornell. edu/usda/nass/NursProd//2000s/ 2007/NursProd-09-26-2007.pdf>.

United Nations Environment Programme. 1999. The Montreal Protocol on substances that deplete the ozone layer as either adjusted and/or amended in London 1990, Copenhagen 1992, Vienna 1995, Montreal 1997, Beijing 1999. Nairobi, Kenya: Ozone Secretariat. 4 Apr. 2013. <http://hq.unep.org/ozone/ pdfs/Montreal-Protocol2000.pdf $>$.

Zasada, I.A., T.W. Walters, and B.D. Hanson. 2010. Challenges in producing nematode and pathogen free fruit and nut nursery crops in the United States. Outlooks Pest Mgt. 21:246-250.

Zheljazkov, V.D., K. Patterson, K.J. Parsons, and G. Sampson. 2007. Tolerance of bare-root ornamental perennials to selected herbicides. Can. J. Plant Sci. 87:439-442. 